\title{
РАСПРЕДЕЛЕНИЕ ЛЕСНЫХ КВАРТАЛОВ ПО ЛЕСНИЧЕСТВАМ НАЦИОНАЛЬНОГО ПАРКА «МАРИЙ ЧОДРА»
}

\author{
П.М. Мазуркин ${ }^{1}$, Н.Г. Эльтерова ${ }^{2}$, \\ ${ }^{1}$ Доктор технических наук, профессор, академик ЕАЕ, РАЕ и РАЕН, \\ зав. кафедрой природообустройства, kaf_po@mail.ru, \\ ${ }^{2}$ магистрант 2 курса по направлению 20.04.01 «Техносферная безопасность» \\ направленности «Охрана природной среды особо охраняемых территорий», \\ Поволжский государственный технологический университет, \\ Йошкар-Ола, Республика Марий Эл, Россия
}

Рассмотрены распределения лесных кварталов по пяти функциональным зонам и четырем лесничествам национального парка «Марий Чодра» по площади, численности лесных пожаров за период 1987-2011 годы, численности лесных кварталов без возникновения на них лесных пожаров, а также по численности лесных кварталов, в которых произошел хотя бы один лесной пожар. Выявлено, что наилучшим по экологической приемлемости при минимальной численности лесных пожаров является Керебелякское лесничество. Относительно него в дальнейшем проведено статистическое моделирование для выявления закономерностей распределения лесных земельных участков, лесных выделов с деревьями, доле пород и параметров средних лесных деревьев.

Ключевые слова: лесные квартала, численность без и с пожарами, количество пожаров, сравнение функциональных зон, выбор лучшего лесничества

\section{THE DISTRIBUTION OF FOREST DISTRICTS NATIONAL PARK "MARIY CHODRA"}

${ }^{1}$ P. M. Mazurkin, ${ }^{2}$ N.G. Elterova

${ }^{1}$ Doctor of Technical Sciences, Professor, Department of environmental engineering,

${ }^{2}$ the 2-year student 20.04.01 in the direction of "Technosphere safety"

direction "Protection of natural environment protected areas",

Volga State University of Technology, Yoshkar-Ola, Republic of Mari El, Russian Federation Corresponding author: kaf_po@mail.ru

The described distribution of forest areas in five functional areas and four corners forest national Park "Mariy Chodra" in size, the number of forest fires for the period 1987-2011 years, the number of forest blocks without causing them forest fires, and the number of forest districts that experienced at least one wildfire. It is revealed that the top environmental acceptability with a minimum number of forest fires is Karabulakskiy forestry. Regarding further conducted statistical modeling to identify regularities of distribution of forest land, forest areas with trees, proportion of species and parameters of secondary forest trees.

Keywords: forest quarter, the number with and without fires, number of fires, a comparison of functional areas, the selection of the best forestry

Введение. Для выявления устойчивых закономерностей взаимного влияния параметров лесных выделов с деревьями вначале нужно определить ранговые распределения лесных земельных участков. Как известно, единицей территориального измерения лесного массива общепринято лесничество. Поэтому относительно него нужно изучить параметр площади. 
Однако лесничества многих лесных предприятий ныне имеют расстроенные леса. Поэтому вначале, как мы предлагаем, нужно изучать лучшие лесничества на территориях национальных парков и заповедников. Под критерием «лучший» мы понимаем те лесничества, лесные кварталы которых наименее подвержены антропогенному воздействию различными видами рубок деревьев. Кроме того, лучшим лесничеством становится та территория, на которой во всех лесных кварталах возникали наименьшее количество лесных пожаров.

Национальные парки, в соответствии с Федеральным законом Российской Федерации «Об особо охраняемых природных территориях» (1995 г.), являются природоохранными, эколого-просветительскими и научноисследовательскими учреждениями. Их территории (акватории) включают в себя природные комплексы и объекты, имеющие особую экологическую, историческую и эстетическую ценность. Они предназначены для использования в природоохранных, просветительских, научных и культурных целях, а также для регулируемого туризма и отдыха.

Цели национального парка определяют круг проблем, решение которых предстоит парку [9-11]:

- сохранение целостности и своеобразия равнинных, холмистых и прирусловых ландшафтов парка, речных систем и акваторий озер, растительности и животного мира, памятников природы, истории и культуры;

- создание условий для полноценного туристического и экскурсионного отдыха, ознакомления с природой, культурными и историческими памятниками парка;

- разработка и внедрение оптимального режима и норм рекреационного и хозяйственного использования всего природного комплекса парка и его компонентов (с учетом предельно допустимых рекреационных нагрузок);

- разработка и внедрение научных методов, восстановление нарушенных хозяйственной и рекреационной деятельностью природных комплексов;

- организация экологического мониторинга в экосистемах национального парка;

- организация экологического просвещения населения, пропаганда природоохранных и краеведческих знаний.

Задачи национального парка - это конкретные вопросы жизнедеятельности парка. В соответствии с ними парк осуществляет:

- охрану территории от захвата земель, пожаров, самовольных рубок, браконьерства и прочих нарушений природной среды;

- ащиту растительности от вредителей и болезней;

- проведение рубок ухода за лесом, санитарных рубок и уборку захламленности вблизи туристических приютов в порядке мер ухода за лесной средой; 
- благоустройство территории для туризма и экскурсий;

- мероприятия по сохранению и воспроизводству флоры и фауны.

Кроме того, национальный парк выполняет следующие функции:

- регулирует интенсивность рекреационного и хозяйственного использования отдельных функциональных зон парка;

- выдает регистрационные удостоверения на все виды деятельности, осуществляемые различными организациями на территории парка;

- организует и осуществляет туризм;

- разрабатывает и вносит на рассмотрение администраций районов и правительства Республики Марий Эл предложения по регламентации деятельности различных организаций в охранной (буферной) зоне национального парка.

Национальный парк «Марий Чодра» (Марийский лес) - это удивительные по красоте и разнообразию леса, луга, реки, озера и болота.

Важно отметить, что национальный парк «Марий Чодра» создан для того, чтобы охранять и защищать природу, решать задачи в области экологического просвещения, науки и туризма.

Важно отметить, что этот национальный парк был создан в 1985 году на территории, где ранее леса подвергались рубкам. Таким образом, лесная территория была подвержена антропогенному воздействию. И за 31 год структура пород деревьев мало изменилась.

В связи с этим важно будет сравнить в будущем выявленные закономерности с теми лесничествами, на которых произрастают девственные леса (например, в Сибири и Дальнем Востоке). Только после этого можно будет приступать к статистическому моделированию параметров лесных земельных участков и лесных выделов у лесничеств лесных предприятий с сильно расстроенными лесными массивами.

Национальный парк «Марий Чодра» расположен в южной части Республики Марий Эл на территории трех административных районов: Звениговского - 13146 га, Волжского - 17708 га, Моркинского - 6021 га. Протяженность территории парка с севера на юг - 34 км, с запада на восток - 25 км. На севере и на западе национальный парк граничит с Звениговским, на востоке - с Куженерским, на юге и юго-востоке - с Алексеевским лесхозами. Общая площадь парка составляет 36875 га [9-11].

Лесной фонд национального парка представлен на 55\% хвойными, около $2 \%$ твердолиственными и $43 \%$ мягколиственными насаждениями. Хвойные насаждения на 92\% состоят из сосняков, в основном, 3-5 классов возраста и ельники 4-7 классов возраста - 8\%. Мягколиственные насаждения представлены, в основном, березой (63\%) 6-9 классов возраста, осиной (12\%) 5-9 классов возраста и липой (19\%) 6-12 и выше классов возраста. Малый процент территории занимают другие породы, такие как дуб, клен, вяз, пихта, лиственница, ольха черная, ива древовидная.

В административно-хозяйственном отношении территория нацио- 
нального парка разделена на 4 лесничества (таблица 1).

Таблица 1. Административно-хозяйственная структура

\begin{tabular}{|c|c|c|c|}
\hline \multicolumn{4}{|c|}{ и общая площадь национального парка «Марий Чодра» } \\
\hline $\begin{array}{l}\text { № } \\
\Pi / \Pi\end{array}$ & Лесничество & $\begin{array}{c}\text { Административный } \\
\text { район }\end{array}$ & $\begin{array}{c}\text { Общая } \\
\text { площадь, га }\end{array}$ \\
\hline \multirow{3}{*}{1} & \multirow{3}{*}{ Керебелякское } & Звениговский & 3867 \\
\hline & & Моркинский & 6021 \\
\hline & & Итого & 9888 \\
\hline \multirow{3}{*}{2} & \multirow{3}{*}{ Кленовогорское } & Звениговский & 1087 \\
\hline & & Волжский & 9310 \\
\hline & & Иmozo & 10397 \\
\hline \multirow{3}{*}{3} & \multirow{3}{*}{ Лушмарское } & Волжский & 693 \\
\hline & & Звениговский & 8912 \\
\hline & & Иmого & 9705 \\
\hline \multirow[t]{6}{*}{4} & Яльчинское & Волжский & 7705 \\
\hline & & Иmого & 7705 \\
\hline & \multirow{4}{*}{ Итого по парку } & Волжский & 17708 \\
\hline & & Звениговский & 13146 \\
\hline & & Моркинский & 6021 \\
\hline & & Bcezo & 36875 \\
\hline
\end{tabular}

На рисунке 1 показано расположение национального парка на карте Республики Марий Эл [9-11].

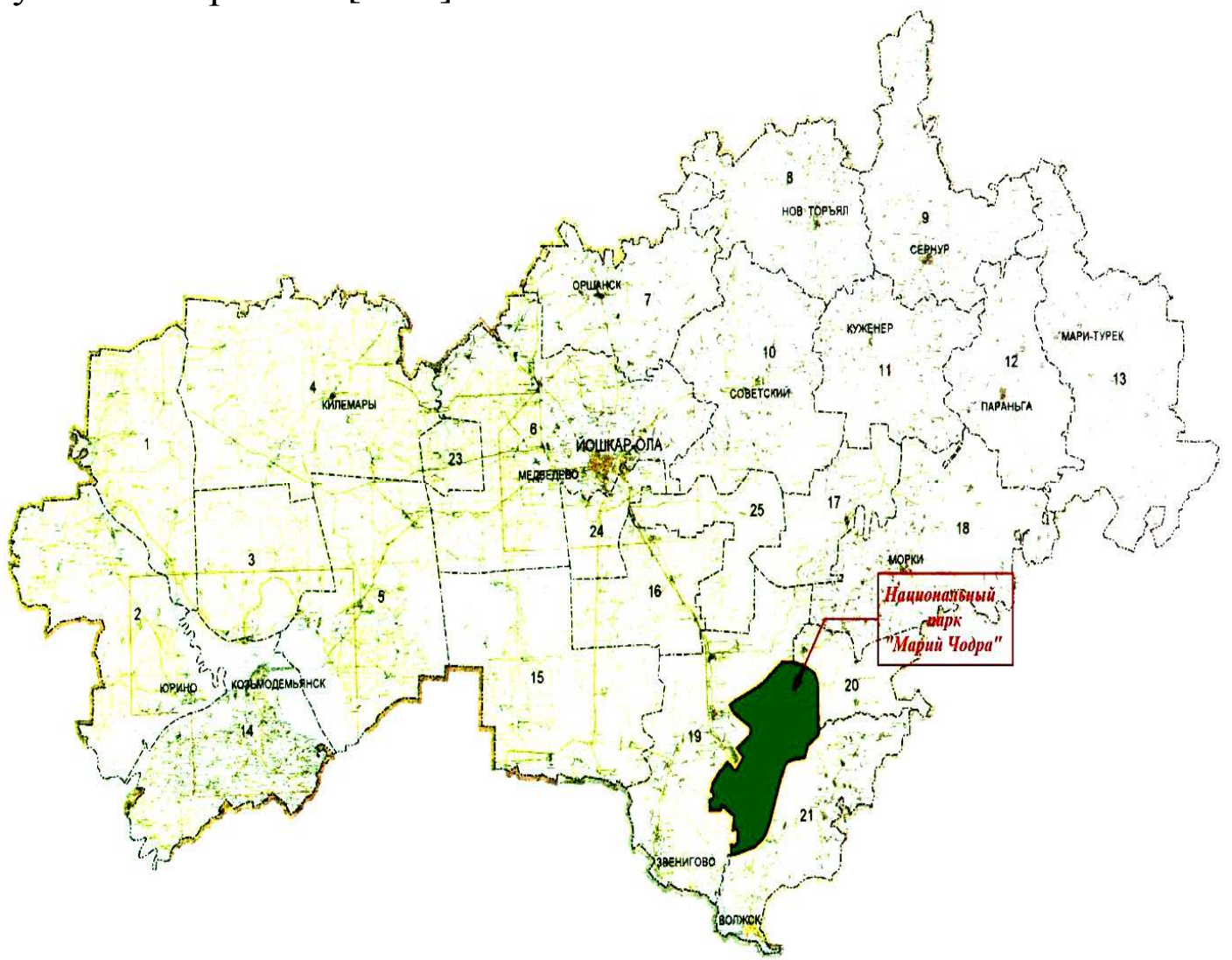

Рис. 1. Местоположение ФГУ «Национальный парк «Марий Чодра» на карте Республики Марий Эл 
Государственный природный Национальный парк «Марий Чодра» был организован 1 декабря 1985 года. Марий Чодра, в переводе, означает «марийский лес». И назван он так не случайно - вся территория парка покрыта прекрасными сосновыми борами и хвойно-широколиственными лесами. Парк находится на юго-востоке республики, в трех муниципалитетах - Моркинском, Звениговском, Волжском - в 20-40 км от г. Волжска и 50-70 км от г. Йошкар-Олы.

Физико-географические условия. Национальный парк расположен на юго-востоке Республики Марий Эл, в бассейне р. Илеть - левого притока Волги, и входит в полосу смешанных лесов лесной зоны. Территория представляет собой слабоволнистую равнину с абсолютными высотами 75125 метров над уровнем моря.

На территории парка расположено большое количество озер и рек. Главная река парка - Илеть с ее левобережными притоками: Юшут, Арбайка, Уба, справа в нее впадает река Петъялка. В течение теплого периода года водность реки позволяет проходить туристским лодкам. В районе Кленовой горы в Илеть выходят более 20 источников. Наиболее значительный - Зеленый ключ, бьющий у подошвы горы на левом берегу Илети.

Лесные карстовые озер чистые и прозрачные, некоторые их них Яльчик, Глухое, Кичиер, Шулгандан - являются памятникам природы.

Климат территории расположения национального парка умеренноконтинентальный, характеризуется сравнительно жарким летом и морозной зимой с устойчивым снежным покровом. Средняя температура самого теплого месяца (июля) $+18,3^{\circ} \mathrm{C}$, самого холодного (январь) $-14,1^{\circ} \mathrm{C}$.

Парк «Марий Чодра» занимает площадь 36,6 тыс. га. Благодаря положению на стыке геологических структур и природных зон здесь создается значительное разнообразие ландшафтов.

В рельефе преобладают равнины, хотя их поверхность разная на западе и востоке территории парка. В западной ее части равнины сложены мощной толщей песчаных отложений, нанесенных реками и талыми водами ледника. На поверхности этих равнин встречаются невысокие холмы, западины, вытянутые гряды.

В восточной части парка распространены, в основном, приподнятые, возвышенные равнины. Поверхность их весьма разнообразна. Керебелякская возвышенность, например, имеет характер волнистого плато с крутыми склонами; Кленовогорская - облик куполовидного поднятия. Фундамент этих равнин слагают известняки, доломиты, мергели, гипсы, т. е. породы, накапливавшиеся здесь в том далеком геологическом прошлом, когда на Русской равнине существовало море.

Например, котловины почти всех озер имеют провально-карстовое происхождение. Большие озера занимают ванны, образованные слившимися провалами, таковы Мушан-ер и Глухое озеро. Карстовые воронки можно осмотреть в районе озера Яльчик. 
На рисунке 2 изображен памятник природы озеро Яльчик - крупнейшее карстовое озеро на территории Республики Марий Эл.

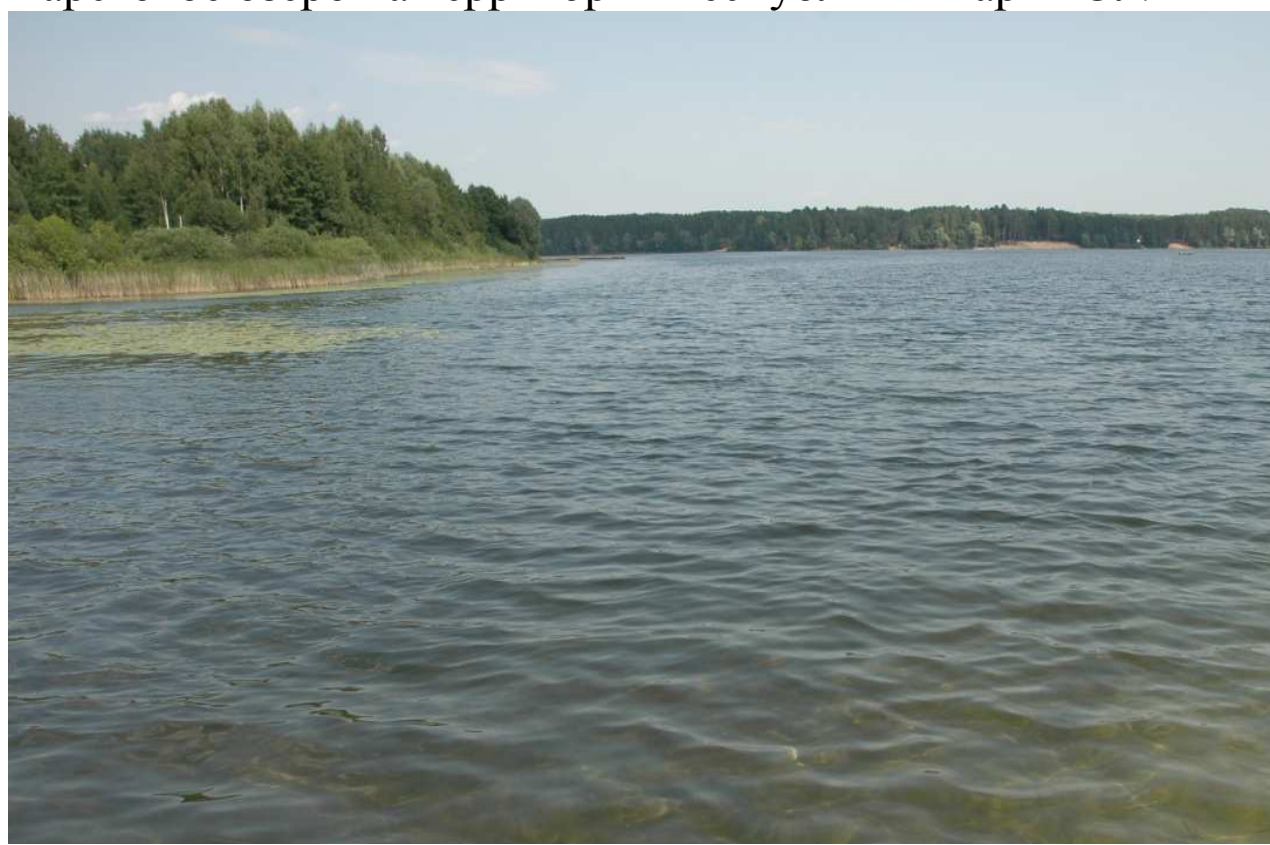

Рис. 2. Озеро Яльчик

Крупнейшая водная артерия на территории национального парка река Илеть. Это левый приток Волги. Илеть течет в широкой долине, что позволяет ей делать петлеобразные изгибы - меандры.

На рисунке 3 показана карта с нанесенными на нее функциональными зонами на территории ФГУ «Национальный парк «Марий Чодра».

Эти функциональные зоны на территории имеют четкую структурнофункциональную иерархию по вектору предпорядка предпочтительности «лучше $\rightarrow$ хуже». Поэтому можно ранжировать эту иерархию, начиная от ранга 0 , со следующими условными обозначениями функциональных зон:

Ф31 - зона заповедного режима $(R=0)$;

Ф32 - особо охраняемая зона $(R=1)$;

$\Phi 33$ - зона экстенсивной рекреации $(R=2)$;

Ф34 - зона интенсивной рекреации $(R=3)$;

Ф35 - зона хозяйственного назначения $(R=4)$.

В таблице 2 приведено распределение лесных кварталов по лесничествам (столбцы) и функциональным зонам (строки).

Таблица 2. Всего лесных кварталов в национальном парке «Марий Чодра»

\begin{tabular}{|c|c|c|c|c|c|}
\hline \multirow[b]{2}{*}{$\begin{array}{c}\text { Функцио- } \\
\text { нальные зоны }\end{array}$} & \multicolumn{4}{|c|}{ Лесничество } & \multirow[b]{2}{*}{ Итого } \\
\hline & $\begin{array}{l}\text { Керебе- } \\
\text { лякское }\end{array}$ & $\begin{array}{c}\text { Кленово- } \\
\text { горское }\end{array}$ & $\begin{array}{l}\text { Лушмар- } \\
\text { ское }\end{array}$ & $\begin{array}{l}\text { Яльчин- } \\
\text { ское }\end{array}$ & \\
\hline Ф31 & 57 & 12 & 0 & 0 & 69 \\
\hline Ф32 & 3 & 20 & 12 & 4 & 39 \\
\hline Ф33 & 22 & 29 & 43 & 13 & 107 \\
\hline Ф34 & 1 & 32 & 33 & 44 & 110 \\
\hline Ф35 & 1 & 5 & 4 & 12 & 22 \\
\hline Итого & 84 & 98 & 92 & 73 & 347 \\
\hline
\end{tabular}




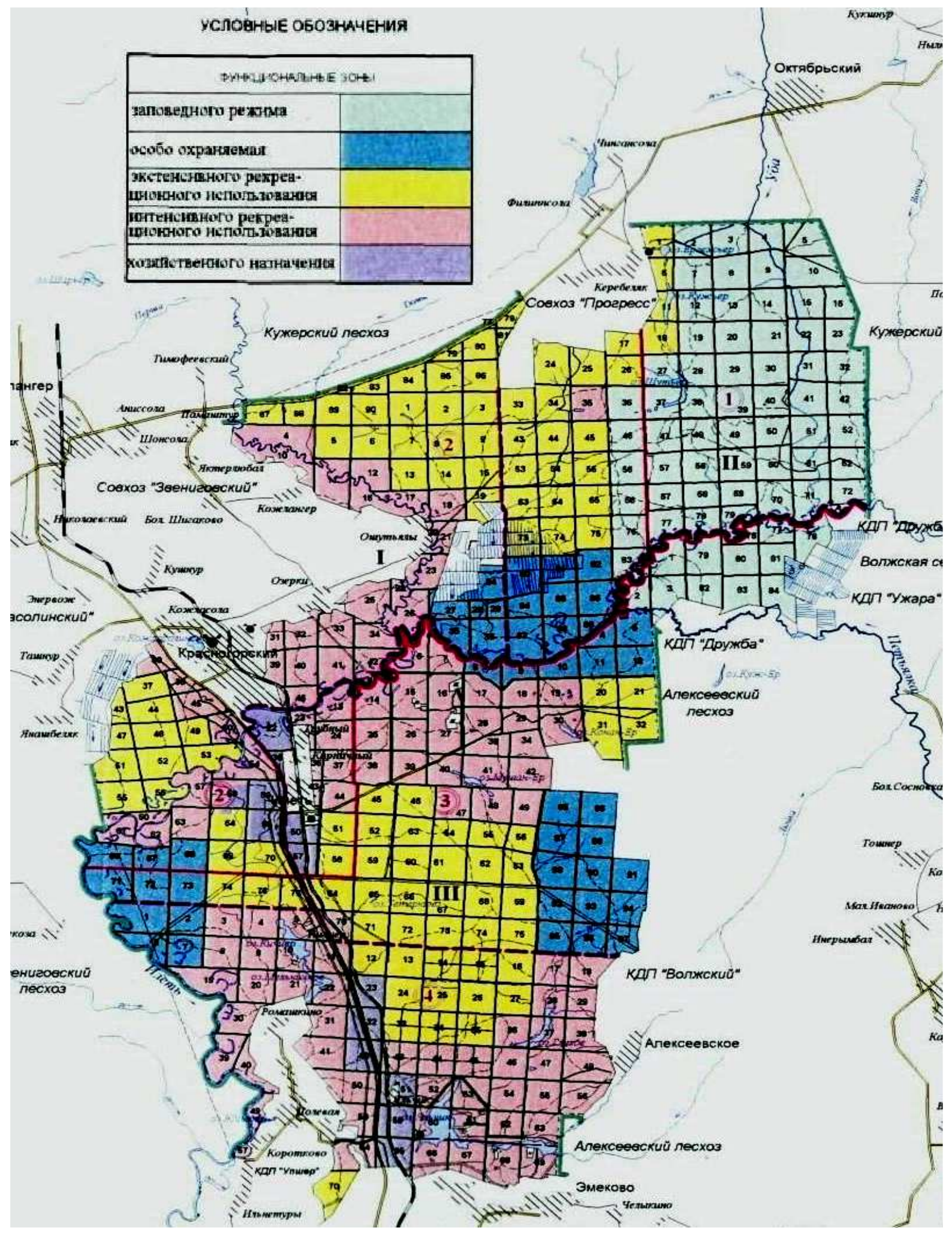

Рис. 3. Карта-схема территории национального парка «Марий Чодра» с разделением на функциональные зоны и лесные квартала

Как видно из данных таблицы 2, наибольшее количество (57 из 69) лесных кварталов зоны заповедного режима находится на территории Керебелякского лесничества. 
На рисунке 4 изображены границы четырех лесничеств национального парка «Марий Чодра».

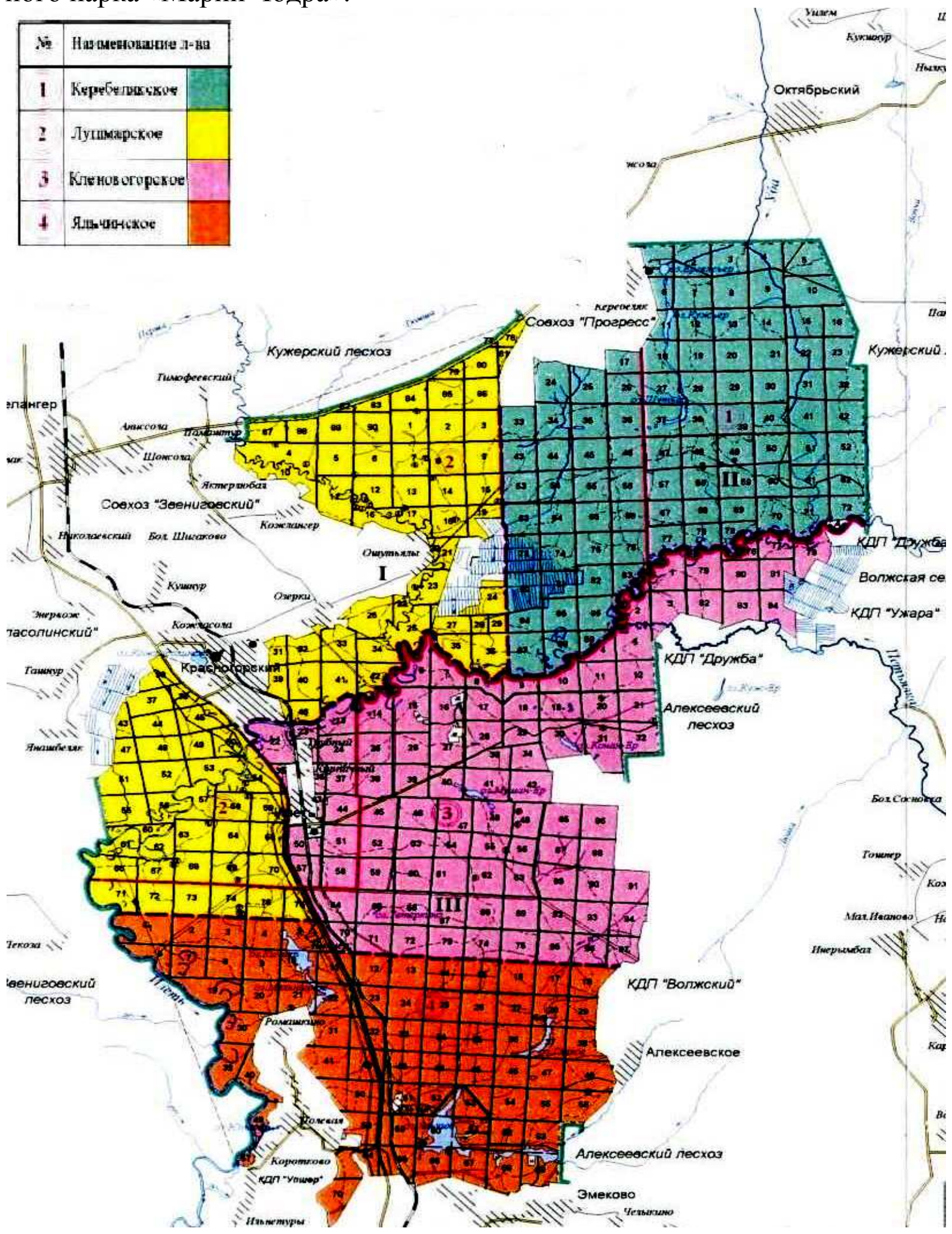

Рис. 4. Карта-схема административного распределения лесничеств в ФГУ «Национальный парк «Марий Чодра»

В таблице 2 лесничества расположены по убыванию числа кварталов 
зоны заповедного режима. В магистерской диссертации Комаровой Е.А. показаны закономерности распределения лесных кварталов по функциональным зонам и лесничествам (табл. 3).

Регистрация лесных пожаров. Книга учета лесных пожаров ФГБУ «Национальный парк «Марий Чодра» представляет собой журнал, в котором составитель акта о пожаре парка или лесничества, где произошло возгорание, записывает все известные ему данные о возгорании.

В таблице 3 приведено количество пожаров с учетом распределения их количества за 23 года по функциональным зонам и лесничествам. До 1987 года распределение лесничеств и их лесных кварталов было иным.

Таблица 3. Динамика лесных пожаров по функциональным зонам и лесничествам на территории национального парка «Марий Чодра» за 1987-2009 гг., шт.

\begin{tabular}{|c|c|c|c|c|c|c|c|}
\hline \multirow{3}{*}{$\begin{array}{c}\text { Наименование } \\
\text { лесничества } \\
\text { (по алфавиту) }\end{array}$} & \multirow{3}{*}{$\begin{array}{l}\text { Рейтин- } \\
\text { говое } \\
\text { место } j\end{array}$} & \multicolumn{5}{|c|}{ Функциональные зоны с рейтинговыми местами $i$} & \multirow{3}{*}{$\begin{array}{c}\text { Коли- } \\
\text { чество } \\
\text { лесных } \\
\text { пожа- } \\
\text { ров } \\
N_{j} \text {, шт }\end{array}$} \\
\hline & & $\begin{array}{c}\text { Запо- } \\
\text { ведный } \\
\text { режим }\end{array}$ & \begin{tabular}{|c|} 
Особо \\
охраня- \\
емая
\end{tabular} & $\begin{array}{c}\text { Экстен- } \\
\text { сивной } \\
\text { рекреа- } \\
\text { ции } \\
\end{array}$ & $\begin{array}{c}\text { Интен- } \\
\text { сивной } \\
\text { рекреа- } \\
\text { ции } \\
\end{array}$ & \begin{tabular}{|c} 
Хозяйст- \\
венного \\
назначения
\end{tabular} & \\
\hline & & 1 & 2 & 3 & 4 & 5 & \\
\hline Керебелякское & 1 & 5 & 0 & 2 & 0 & 0 & 7 \\
\hline Кленовогорское & 2 & 1 & 5 & 14 & 23 & 9 & 52 \\
\hline Лушмарское & 3 & 0 & 7 & 17 & 37 & 4 & 65 \\
\hline Яльчинское & 4 & 0 & 2 & 27 & 100 & 13 & 142 \\
\hline Всего по пар & $N_{i}$ & 6 & 14 & 60 & 160 & 26 & $N=260$ \\
\hline
\end{tabular}

Ранжирование рейтинговых мест $i$ функциональных зон было выполнено изначально по росту антропогенной нагрузки. При этом $i=R+1$. А список лесничеств официально заполняется по алфавиту. Но мы расставили рейтинговые места $j$ по увеличению количества лесных пожаров. И этот рейтинг совпал с расположением лесничеств по данным таблицы 2.

Таким образом, влияющая переменная $i$ задана изначально по росту антропогенной нагрузки, а влияющая переменная $j$ была по росту числа лесных пожаров за многолетний период. Поэтому ранжирование лесничеств по параметру $j$ зависит от конкретной лесной территории.

Наибольшее количество пожаров (160 шт.) наблюдается в зоне интенсивной рекреации. Именно в этой зоне вблизи от транспортных путей и населенных пунктов находятся наиболее освоенные водные объекты отды$\mathrm{xa}$, а также природные достопримечательности национального парка и туристические маршруты.

В зоне заповедного режима наличие пожаров минимально и равно всего 6 шт., из которых 5 лесных пожаров произошли в Керебелякском лесничестве. Доступ населения в зону заповедного режима запрещен, и все пять возгораний были от грозовой деятельности, то есть возникли по естественным, а не по антропогенным, причинам. 
На пространственном графике (рис. 5) четко просматривается влияние обоих рейтинговых мест $i$ и $j$ на распределение лесных пожаров за многолетний период [1-5].

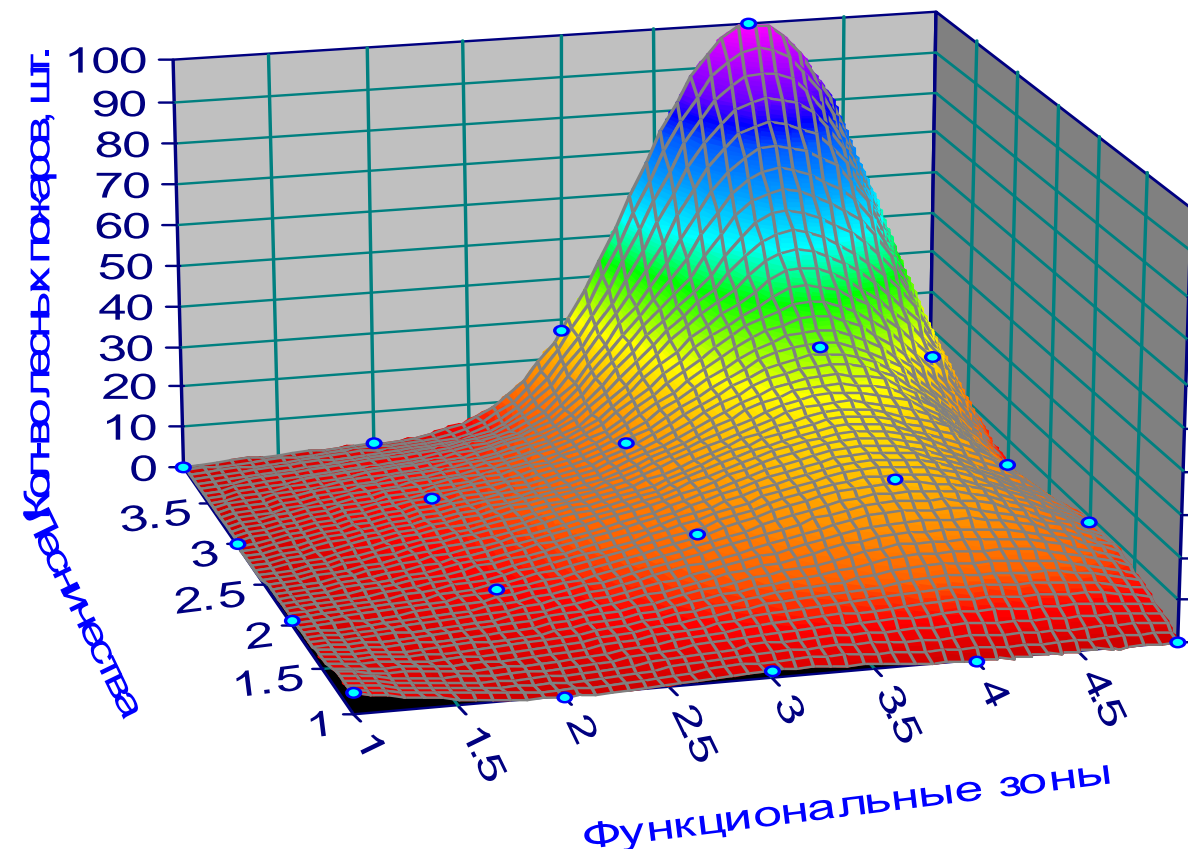

Рис. 5. Пространственный график изменения общей численности лесных пожаров за 1982-2009 гг. в зависимости от рейтинговых мест функциональных зон и лесничеств

Общая модель распределения количества всех пожаров по функциональным зонам (последняя строка таблицы 3) характеризуется (рис. 6) двухчленным уравнением

$$
\begin{gathered}
N_{i}=6,50859 \exp (0,27909 i)+ \\
+2,21723 i^{164,4702} \exp (-46,17848 i),
\end{gathered}
$$

где $\quad N_{i}$ - количество лесных пожаров всего, шт.,

$i$ - рейтинговое место функциональной зоны.

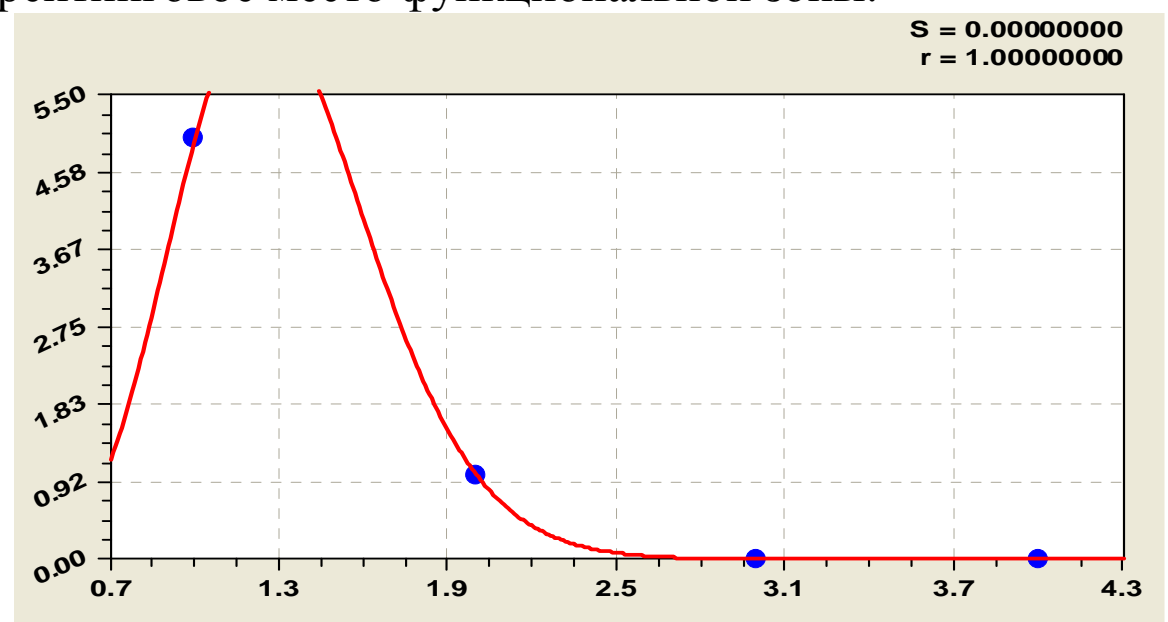

Рис. 6. График распределения многолетних лесных пожаров по заповедному режиму национального парка «Марий Чодра»

Наименьшее количество пожаров есть в заповедном режиме (6 шт.). 
В целом по всем функциональным зонам распределение лесничеств по количеству пожаров подчиняется (рис. 7) формуле

$$
N_{j}=10,06720 j^{1,88425},
$$

где $\quad N_{j}$ - количество лесных пожаров лесничествам, шт.,

$j$ - рейтинговое место лесничества.

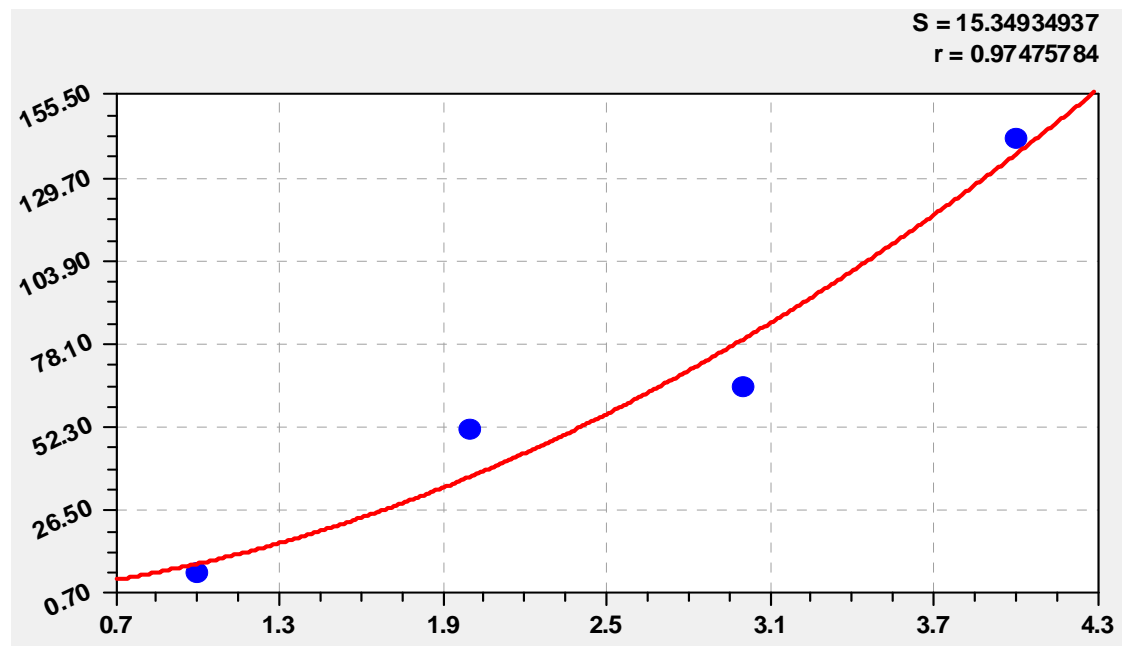

Рис. 7. График распределения общей численности лесных пожаров за 1982-2009 гг. по лесничествам с учетом их рейтинговых мест

График распределения лесных пожаров по Керебелякскому лесничеству национального парка «Маий-Чодра» приведен на рисунке 8.

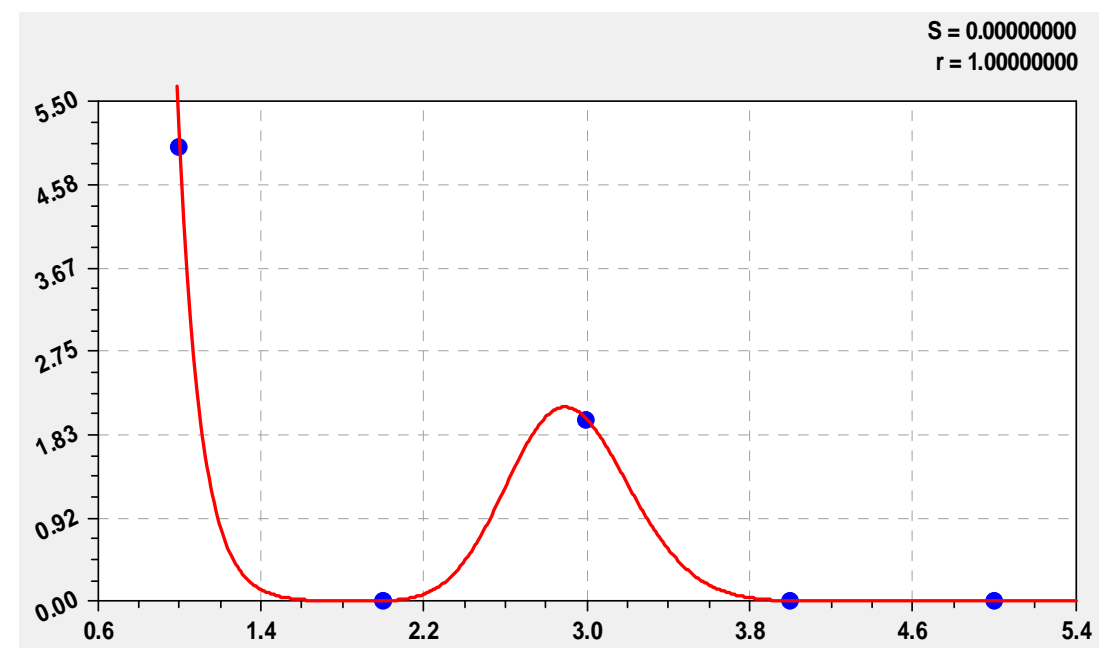

Рис. 8. Лесные пожары за 1982-2009 гг. в Керебелякском лесничестве

Влияние аномального 2010 года. За два года регистрации (дополнительно 2010 и 2011 годы) количество лесных пожаров по национальному парку «Марий Чодра» возросло с 266 (таблица 3) до 293 шт.

При этом количество лесных пожаров за 25 лет регистрации изменяется по данным таблицы 4.

Сравнение данных таблиц 3 и 4 показывает, что 293 лесных пожара произошли на 130 лесных кварталах. Однако среднее арифметическое зна- 
чение числа пожаров не подходит, так как на некоторых лесных кварталах за 25 лет произошло много пожаров. Поэтому за объект исследования нужно брать не сам лесной пожар, а лесной квартал, на котором произошел это пожар.

Таблица 4. Количество лесных пожаров за период 1987-2011 гг.

\begin{tabular}{|c|c|c|c|c|c|}
\hline \multirow{2}{*}{$\begin{array}{c}\text { Функцио- } \\
\text { нальные зоны }\end{array}$} & \multicolumn{4}{|c|}{ Леснебе- } & Кленово- \\
лякское & Горское & $\begin{array}{c}\text { Лушмар- } \\
\text { ское }\end{array}$ & $\begin{array}{c}\text { Яльчин- } \\
\text { ское }\end{array}$ & \\
\hline Гзого & 6 & 1 & 0 & 0 & 7 \\
\hline Ф32 & 0 & 0 & 7 & 3 & 10 \\
\hline$\Phi 33$ & 2 & 23 & 20 & 29 & 74 \\
\hline Ф34 & 0 & 29 & 35 & 96 & 160 \\
\hline Ф35 & 0 & 11 & 5 & 26 & 42 \\
\hline Итого & 8 & 64 & 67 & 154 & 293 \\
\hline
\end{tabular}

В таблице 5 приведено количество пожаров с учетом распределения их количества за 25 лет по лесничествам и по числу пожаров на одном лесном квартале.

Таблица 5. Количество пожаров на лесных кварталах на территории ФГУ «Национальный парк «Марий Чодра» за 1987-2011 гг. по лесничествам

\begin{tabular}{|c|c|c|c|c|c|}
\hline \multirow{2}{*}{$\begin{array}{c}\text { Количество } \\
\text { пожаров } \\
\text { на квартале } \\
n_{\kappa \varepsilon}, \text { шт. }\end{array}$} & \multicolumn{4}{|c|}{ Количество кварталов по лесничествам } & \multirow{2}{*}{$\begin{array}{c}\text { Всего } \\
\text { кварталов } \\
N_{n}, \text { шт. }\end{array}$} \\
\hline & $\begin{array}{l}\text { Керебе- } \\
\text { лякское }\end{array}$ & $\begin{array}{l}\text { Кленово- } \\
\text { горское }\end{array}$ & $\begin{array}{l}\text { Лушмар- } \\
\text { ское }\end{array}$ & $\begin{array}{c}\text { Яльчин- } \\
\text { ское }\end{array}$ & \\
\hline 0 & 76 & 66 & 57 & 18 & 217 \\
\hline 1 & 8 & 18 & 17 & 15 & 58 \\
\hline 2 & 0 & 7 & 12 & 13 & 32 \\
\hline 3 & 0 & 3 & 4 & 11 & 18 \\
\hline 4 & 0 & 1 & 1 & 5 & 7 \\
\hline 5 & 0 & 1 & 0 & 4 & 5 \\
\hline 6 & 0 & 1 & 0 & 1 & 2 \\
\hline 7 & 0 & 0 & 0 & 1 & 1 \\
\hline 8 & 0 & 1 & 0 & 1 & 2 \\
\hline 9 & 0 & 0 & 0 & 1 & 1 \\
\hline 10 & 0 & 0 & 1 & 1 & 2 \\
\hline Итого кварт. & 84 & 98 & 92 & 71 & $345^{*}$ \\
\hline Итого пожаров & 8 & 64 & 67 & 154 & 293 \\
\hline
\end{tabular}

Примечание: *У двух кварталов нет точных данных о пожарах.

Таким образом, все имеющиеся лесные кварталы условно имеют значения частоты лесных пожаров. На тех лесных кварталах, на которых за 25 лет не произошли ни одного лесного пожара, принимается значение количества лесных пожаров на одном и том же лесном квартале $n_{\kappa в}=0$.

Из данных таблицы 5 видно, что в Керебелякском лесничестве все восемь лесных пожаров произошли только по одному на лесном квартале.

Общее количество пожаров $\sum N=293$ шт. определяется по формуле 


$$
\sum N_{n}=\sum_{n_{\kappa \varepsilon}=0}^{10} N_{n} n_{\kappa \varepsilon} .
$$

Аналогично для лесничеств получаем уравнение количества пожаров

$$
\sum N_{J}=\sum_{n_{\kappa \varepsilon}=0}^{10} N_{J} n_{\kappa \varepsilon} .
$$

Из данных таблицы 5 видно, что наибольшее количество пожаров равно 10 и при этом столько пожаров произошло на двух лесных кварталах по всему национальному парку (по одному лесному кварталу Лушмарского и Яльчинского лесничеств).

Далее за влияющую переменную примем $n_{\kappa в}$.

Общее количество кварталов $N_{n}$, в зависимости от разного количества лесных пожаров на одном лесном квартале, изменяется по формуле (рис. 9) закона экспоненциальной гибели

$$
N_{n}=216,9377 \exp \left(-1,29352 n_{\text {кв }}^{0,63570}\right) .
$$

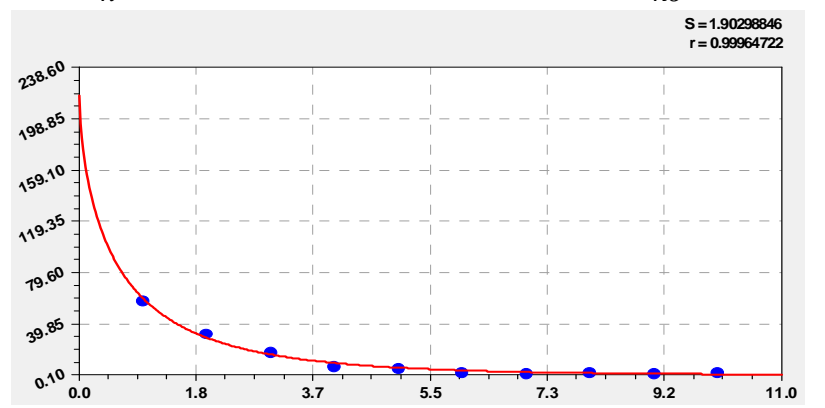

Рис. 9. График распределения кварталов от изменения количества лесных пожаров на одном лесном квартале

Первый параметр при условии $n_{\kappa 6}=0$ показывает количество лесных кварталов без пожаров.

Керебелякское лесничество (рис. 10) получает закономерность вида

$$
N_{J}=76,00875 \exp \left(-2,27275 n_{\text {кв }}\right) \text {. }
$$

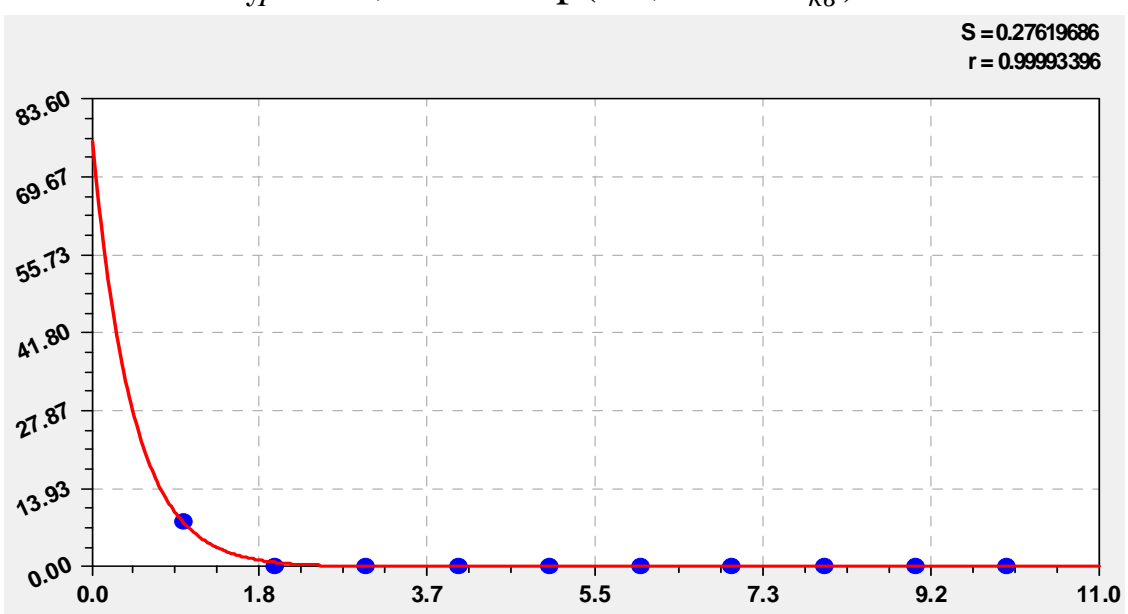

Рис. 10. Распределение лесных кварталов с пожарами по Керебелякскому лесничеству в зависимости от изменения количества лесных пожаров на одном лесном квартале 
Распределение по функциональным зонам. Распределения лесных пожаров по функциональным зонам даны в таблице 6.

Таблица 6. Количество пожаров на лесных кварталах за 1987-2011 гг. по функциональным зонам

\begin{tabular}{|c|c|c|c|c|c|c|}
\hline \multirow{3}{*}{$\begin{array}{c}\text { Количество } \\
\text { пожаров } \\
\text { на } \\
\text { квартале } \\
n_{\text {кв }}, \text { шт. }\end{array}$} & \multicolumn{5}{|c|}{$\begin{array}{c}\text { Количество кварталов } \\
\text { по функциональным зонам }\end{array}$} & \multirow{3}{*}{$\begin{array}{c}\text { Всего } \\
\text { по } \\
\text { парку } \\
N_{n}, \text { шт }\end{array}$} \\
\hline & $\begin{array}{c}\text { Заповед- } \\
\text { ного }\end{array}$ & $\begin{array}{c}\text { особо } \\
\text { охраняя }\end{array}$ & $\begin{array}{l}\text { экстенс. } \\
\text {-рекреац. }\end{array}$ & $\begin{array}{l}\text { интенс. } \\
\text { иекреац. }\end{array}$ & $\begin{array}{c}\text { Хозяй- } \\
\text { ственного }\end{array}$ & \\
\hline & режима & емая & использ. & іспольз. & назначения & \\
\hline 0 & 62 & 32 & 72 & 47 & 4 & 217 \\
\hline 1 & 7 & 4 & 14 & 29 & 4 & 58 \\
\hline 2 & 0 & 3 & 14 & 10 & 5 & 32 \\
\hline 3 & 0 & 0 & 3 & 12 & 3 & 18 \\
\hline 4 & 0 & 0 & 1 & 4 & 2 & 7 \\
\hline 5 & 0 & 0 & 2 & 2 & 1 & 5 \\
\hline 6 & 0 & 0 & 0 & 1 & 1 & 2 \\
\hline 7 & 0 & 0 & 0 & 1 & 0 & 1 \\
\hline 8 & 0 & 0 & 0 & 2 & 0 & 2 \\
\hline 9 & 0 & 0 & 1 & 0 & 0 & 1 \\
\hline 10 & 0 & 0 & 0 & 2 & 0 & 2 \\
\hline Итого кв. & 69 & 39 & 107 & 110 & 20 & 345 \\
\hline Итого пож. & 7 & 10 & 74 & 160 & 42 & 293 \\
\hline
\end{tabular}

Для функциональных зон получаем уравнение количества пожаров

$$
\sum N_{\Phi 3}=\sum_{n_{\kappa 6}=0}^{10} N_{\Phi 3} n_{\kappa 6} .
$$

Тогда, снимая индексы, в общем случае получаем выражение для подсчета общего числа лесных пожаров по лесничествам и функциональным зонам национального парка вида

$$
\Sigma_{N}=\sum_{n_{K \varepsilon}=0}^{n_{\max }} N_{\left(n_{k \varepsilon}\right)} \cdot n_{\kappa \varepsilon},
$$

где $\sum_{N}$ - сумма лесных пожаров по подразделениям лесного предприятия, Шт.,

$n_{\kappa в}$ - количество лесных пожаров на лесном квартале, шт.,

$n_{\max }$ - максимальное количество лесных пожаров за период измерений на одном лесном квартале, шт.,

$N_{\left(n_{k \varepsilon}\right)}$ - количество лесных кварталов с данным значением $n_{\kappa в}$ при изменении в интервале $0 \leq n_{\kappa 6} \leq n_{\max }$, шт.

На зоне заповедного режима (рис. 11) получена зависимость вида

$$
N_{\Phi 3}=62,00936 \exp \left(-2,20579 n_{\kappa 6}\right) \text {. }
$$

На особо охраняемой зоне (графики даны в [3]) выполняется закон экспоненциальной гибели 


$$
N_{\Phi 3}=31,95113 \exp \left(-1,92286 n_{\kappa \varepsilon}\right) .
$$

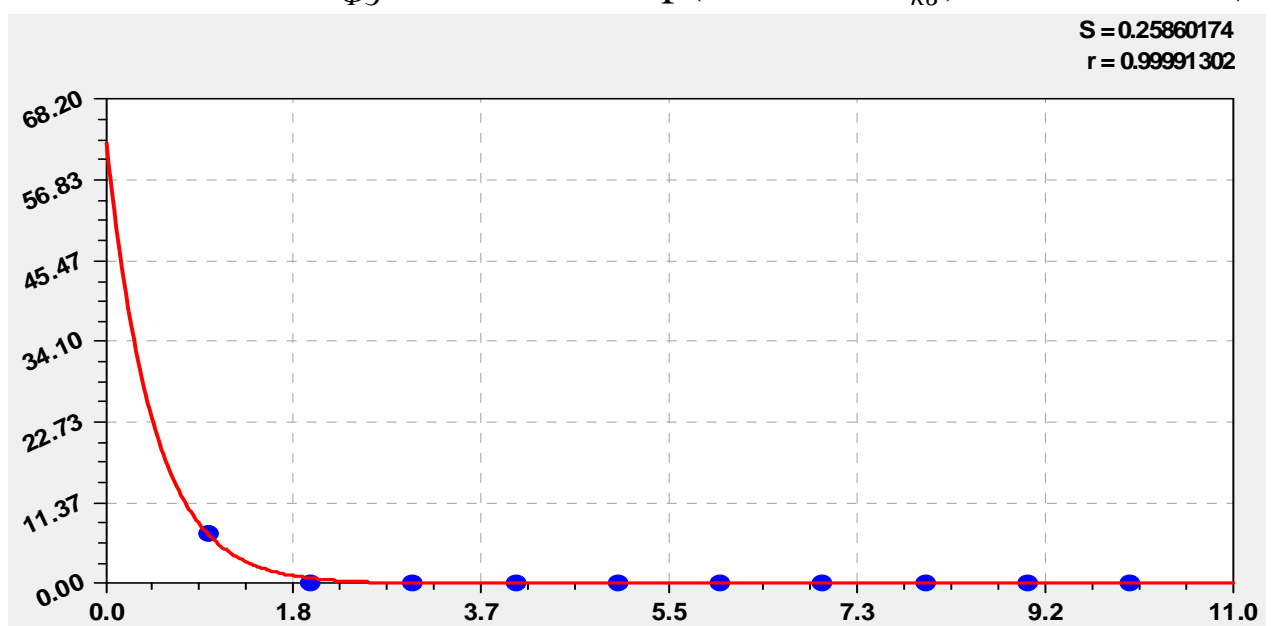

Рис. 11. График распределения лесных кварталов с разным количеством лесных пожаров по зоне заповедного режима

На функциональной зоне экстенсивного рекреационного использования получился закон экспоненциальной гибели:

$$
N_{\Phi 3}=71,94865 \exp \left(-1,49370 n_{\kappa в}^{0,54817}\right) \text {. }
$$

На функциональной зоне интенсивного рекреационного использования лесных земельных участков:

$$
N_{\Phi 3}=47,28909 \exp \left(-0,56464 n_{\kappa в}^{1,03489}\right) \text {. }
$$

На зоне хозяйственного назначения количество лесных кварталов распределяется по биотехнической закономерности вида

$$
N_{\Phi 3}=4,33407 \exp \left(-0,010234 n_{\kappa в}^{3,01562}\right) \text {. }
$$

Таким образом, общая закономерность [3] у всех распределений это закон гибели в экспоненциальной форме.

Лесные квартала без пожаров. Для оценки экологического качества функциональных зон и лесничеств следует учитывать количество и долю лесных кварталов, на которых с 1982 по 2011 годы не произошло ни одного лесного пожара. Однако данные имеются только с 1987 года.

Количество лесных кварталов без пожаров дано в таблице 7.

Таблица 7. Всего лесных кварталов без пожаров за 1987-2011 гг.

\begin{tabular}{|c|c|c|c|c|c|}
\hline $\begin{array}{c}\text { Функцио- } \\
\text { нальные зоны }\end{array}$ & \multicolumn{4}{|c|}{ Лесничество } & Керебе- \\
лякское & $\begin{array}{c}\text { Кленово- } \\
\text { горское }\end{array}$ & $\begin{array}{c}\text { Лушмар- } \\
\text { ское }\end{array}$ & $\begin{array}{c}\text { Яльчин- } \\
\text { ское }\end{array}$ & Итого \\
\hline$\Phi 31$ & 51 & 11 & 0 & 0 & 62 \\
\hline$\Phi 32$ & 3 & 20 & 7 & 2 & 32 \\
\hline$\Phi 33$ & 20 & 16 & 32 & 4 & 72 \\
\hline$\Phi 34$ & 1 & 17 & 17 & 12 & 47 \\
\hline$\Phi 35$ & 1 & 2 & 1 & 0 & 4 \\
\hline Итого & 76 & 66 & 57 & 18 & 217 \\
\hline
\end{tabular}

Лесные кварталы, на которых хотя бы один раз произошел лесной 
пожара, представлены в таблице 8.

Таблица 8. Всего лесных кварталов, пройденных одним пожаром

\begin{tabular}{|c|c|c|c|c|c|}
\hline \multirow{2}{*}{$\begin{array}{c}\text { Функцио- } \\
\text { нальные зоны }\end{array}$} & \multicolumn{4}{|c|}{ Лесничество } & \multirow[b]{2}{*}{ Итого } \\
\hline & $\begin{array}{l}\text { Керебе- } \\
\text { лякское }\end{array}$ & $\begin{array}{c}\text { Кленово- } \\
\text { горское }\end{array}$ & $\begin{array}{l}\text { Лушмар- } \\
\text { ское }\end{array}$ & $\begin{array}{l}\text { Яльчин- } \\
\text { ское }\end{array}$ & \\
\hline Ф31 & 6 & 1 & 0 & 0 & 7 \\
\hline Ф32 & 0 & 0 & 5 & 2 & 7 \\
\hline Ф33 & 2 & 13 & 11 & 9 & 35 \\
\hline Ф34 & 0 & 15 & 16 & 32 & 63 \\
\hline Ф35 & 0 & 3 & 3 & 12 & 18 \\
\hline Итого & 8 & 32 & 35 & 55 & 130 \\
\hline
\end{tabular}

Для сравнения национального парка с другими лесными предприятиями [6-8] в таблице 9 даны относительная доля лесных кварталов, в которых произошли лесные пожары.

Таблица 9. Доля лесных кварталов, в которых хотя бы один раз был пожар

\begin{tabular}{|c|c|c|c|c|c|}
\hline \multirow{2}{*}{$\begin{array}{c}\text { Функцио- } \\
\text { нальные зоны }\end{array}$} & \multicolumn{4}{|c|}{ Лесничество } & \multirow[b]{2}{*}{ Итого } \\
\hline & $\begin{array}{l}\text { Керебе- } \\
\text { лякское }\end{array}$ & $\begin{array}{l}\text { Кленово- } \\
\text { горское }\end{array}$ & $\begin{array}{l}\text { Лушмар- } \\
\text { ское }\end{array}$ & $\begin{array}{l}\text { Яльчин- } \\
\text { ское }\end{array}$ & \\
\hline Ф31 & 10.53 & 8.33 & 0 & 0 & 10.14 \\
\hline Ф32 & 0.00 & 0.00 & 41.67 & 50.00 & 17.95 \\
\hline Ф33 & 9.09 & 44.83 & 25.58 & 69.23 & 32.71 \\
\hline Ф34 & 0.00 & 46.88 & 48.48 & 72.73 & 57.27 \\
\hline Ф35 & 0.00 & 60.00 & 75.00 & 100.00 & 81.82 \\
\hline Итого & 9.52 & 32.65 & 38.04 & 75.34 & 37.46 \\
\hline
\end{tabular}

Керебелякское лесничество. Данные по этому лесничеству приведены в таблице 10.

Таблица 10. Параметры лесных пожаров за 1991-2011 гг.

в Керебелякском лесничестве

\begin{tabular}{|c|c|c|c|c|c|}
\hline $\begin{array}{c}\text { Дата } \\
\text { регистра- } \\
\text { ции } \\
\begin{array}{c}\text { лесного } \\
\text { пожара }\end{array}\end{array}$ & Лесной \\
квартал & $\begin{array}{c}\text { Функции- } \\
\text { ональная } \\
\text { зона }\end{array}$ & $\begin{array}{c}\text { Расстояние } \\
\text { до центра } \\
\text { квартала } \\
\text { по дороге } \\
L, \text { км }\end{array}$ & $\begin{array}{c}\text { Период } \\
\text { пожара } \\
T, \text { ч }\end{array}$ & $\begin{array}{c}\text { Площадь } \\
\text { лесного } \\
\text { пожара } \\
S, \text { ap }\end{array}$ \\
\hline 23.07 .1992 & 60 & $\Phi 31$ & 22.0 & 3.8 & 2.00 \\
\hline 06.07 .1993 & 55 & $\Phi 33$ & 15.6 & 1.0 & 0.50 \\
\hline 24.07 .2001 & 62 & $\Phi 31$ & 24.4 & 6.0 & 20.00 \\
\hline 09.07 .2002 & 66 & $\Phi 31$ & 13.0 & 11.5 & 5.00 \\
\hline 28.07 .2003 & 47 & $\Phi 31$ & 18.6 & 16.2 & 1.00 \\
\hline
\end{tabular}

Здесь произошло всего 6 пожаров, из которых 5 имеют значения параметров, показанных в таблице 10. При этом 80\% из 5 лесных пожаров произошли в заповедной зоне и только один пожар в зоне экстенсивного рекреационного использования. Поэтому это лесничество требует особого внимания из-за того, что хозяйственная деятельность здесь запрещена и поэтому закономерности должны проявляться гораздо четче, чем в других 
лесничествах. При этом малое количество данных (всего 5) является недостатком для статистического моделирования.

Из этих исходных данных возможно вывить закономерности в виде структурных формул: 1) $T=f(L)$; 2) $S=f(L)$; 3) $S=f(T)$; 4) $T=f(S)$.

Из-за малого количества данных можно идентифицировать только детерминированные модели в виде тренда с одним или двумя членами.

Заключение. Из всех четырех лесничеств национального парка «Марий Эл» особого внимания к моделированию распределений всех лесных земельных участков и лесных выделов (лесных земельных участков, на которых расположены лесные деревья), а также таксационных показателей этих лесных выделов, требует Керебелякское лесничество.

\section{Список литературы}

1. Мазуркин П.М. Анализ лесных пожаров по многолетним статистическим данным // Вестник Воронежского института ГПС МЧС России. Вып. 3(12), 2014. С. 13-22.

2. Мазуркин П.М. Анализ многолетних лесных пожаров по функциональным зонам и лесничествам // Вестник Воронежского института ГПС МЧС России. Вып. 4(13), 2014. С. 42-49.

3. Мазуркин П.М. Анализ лесных кварталов по частоте пожаров // Вестник Воронежского института ГПС МЧС России. Вып. 1(14), 2015. С. 40-46.

4. Мазуркин П.М. Анализ лесных кварталов по численности пожаров и расстоянию от транспортной магистрали // Вестник Воронежского института ГПС МЧС России. Вып. 3(15), 2015. С. 36-47. 36-47.pdf.

5. Мазуркин П.М. Анализ лесных кварталов по численности пожаров и расстоянию от места дислокации пожарной службы // Вестник Воронежского института ГПС МЧС России. Вып. 4(17), 2015. С. 10-21. 10-21.pdf.

6. Мазуркин П.М. Каткова Т.Е. Моделирование многолетней динамики изменения площади лесных пожаров // Вестник Воронежского института ГПС МЧС России. 2013. №1 (6). С.31-37.

7. Мазуркин П.М. Каткова Т.Е. Анализ многолетней динамики удельной площади лесных пожаров // Вестник Воронежского ин-та ГПС МЧС России. 2013. №2 (7). С.37-43.

8. Мазуркин П.М., Каткова Т.Е. Вейвлет-анализ многолетней динамики локальной численности лесных пожаров // Современные проблемы науки и образования. 2013. № 5;

9. Марий Чодра. Национальный парк. URL: http://www.ecotravel.ru/regions/reserves/1/25/105.

10. Марий Чодра. Национальный парк. URL: http://www.floranimal.ru/national/park.php?pid=109.

11. Национальный парк «Марий Чодра». URL: http://mariekology.narod.ru/NationalParkLeft.htm. 